\title{
SUSCEPTIBILITY OF SOME SOYBEAN VARIETIES AND EFFECT OF PLANTING DATES ON INFESTATION WITH WHITE FLY, BEMISIA TABACI (GENN.) IN KAFRELSHEIKH REGION
}

\author{
ABDALLAH , F.E. ${ }^{1}$, H.A. BORAEI ${ }^{2}$ and HEBA M. MOHAMED ${ }^{1}$
}

1. Field Crop Insect Pest Dept., Sakha Agric. Res. Station, Plant Protection Res. Inst., ARC.

2. Economic Entomology Dept., Fac. of Agric., Kafrelsheikh .

(Manuscript received 13 May 2015)

\begin{abstract}
$\mathrm{T}$ he present studies were carried out at the experimental farm of the Faculty of Agriculture, Kafrelsheikh, University, during two successive seasons; 2011 and 2012 to study the susceptibility of five soybean varieties under three planting dates, $1^{\text {st }}$ May, $15^{\text {th }}$ May and $1^{\text {st }}$ June to the infestation with the whitefly, Bemisia tabaci (Genn.). In respect to relative susceptibility, Giza 21 appeared susceptible to nymphs of B. tabaci during the two successive seasons while, Giza 35 was the least infested one. Statistical analysis revealed significant differences among soybean varieties and the average number of $B$. tabaci during the two seasons of study. As for planting dates, the varieties sown on the early planting date had higher population of $B$. tabaci than those sown on the late ones. Statistical analysis show significant differences between the three planting dates. In the recommended planting date, B. tabaci recorded highly significant positive correlation with nitrogen, zinc, manganese, crude protein, total lipids and silica but had negative significant or highly significant correlation with each of phosphorus, potassium, iron, total carbohydrates and total phenols. As a conclusion Giza 35 was the least infested variety by $B$. tabaci which had the highest value of carbohydrates, phenols, iron, phosphorus and potassium.
\end{abstract}

\section{INTRODUCTION}

Soybean, Glycine max L., is one of the important leguminous crop all over the world. Seeds of soybean have high nutritional value for human, animal, fish and birds, being the most important source of protein concentrate from essential amino acids and vegetable oils.

Under field conditions, soybean plants are subjected to be attacked by many insect pests, among the most common and important insects, the whitefly Bemisia tabaci (Genn.) which causes serious damage on soybean plants, either directly by sucking plant juice or indirectly by viral diseases transmition (El-Samahy and Saad, 2010).

In general, the control strategies must be developed to control the pests of soybean without using the conventional pesticides which cause environmental 
pollution, distraction of beneficial insects and pest resistance to many pesticides (John et al., 1986). For all these reasons there is always a need to develop an integrated pest management (IPM) programs (Marlin and Matt, 2007) such select tolerant or resistant varieties as one of the simplest useful tactics in the (IPM) programs (Dent, 1991) and one of the most effective and economical mean of controlling plant pests, and also the first line of defense against pests (El-Komy and Aly, 2004).

Varieties of soybean exhibit variable reactions to the piercing sucking pests infestation depending on plant physical properties or chemical components of plant leaf (Mc Auslane, 1996) as biochemical factors, to a large extent, affect the behaviour and metabolic processes of pest, while morphological factors mostly influence the mechanisms of locomotion, feeding, oviposition, ingestion and digestion of the pest (Kumar, 1984).

So, the present study was carried out to shed light on the effectiveness of varieties and planting dates on the population density of $B$. tabaci on soybean plants during two successive seasons, 2011 and 2012 and relation between leaves components of soybean varieties and infestation with B. tabaci.

\section{MATERIALS AND METHODS}

The present experiments were carried out at the experimental farm of the Faculty of Agriculture, Kafr Elsheikh, University, during two successive seasons, 2011 and 2012 to study the susceptibility of some soybean varieties and effect of planting dates on infestation with whitefly, Bemisia tabaci (Genn.).

The five tested soybean varieties namely; Crawford, Giza 21, Giza 22, Giza 111 and Giza 35 were obtained from Food legumes Research Section, Field Crops Research Institute, Agricultural Research Center. The varieties were cultivated in three planting dates; $1^{\text {st }}$ May (early); $15^{\text {th }}$ May (recommended) and $1^{\text {st }}$ June (late).The experimental area about $1 / 2$ feddan was divided into 45 plots each about of $42 \mathrm{~m}^{2}$ (5 varieties $\times 3$ replicates for each planting date) and replicates arranged at Randomized Complete Block Design. The normal agricultural practices were followed normally without insecticidal treatments throughout the growing season. The investigation started three weeks after planting and continued weekly until the end of the season. To estimate the population density of $B$. tabaci (nymphs) on the involved varieties, weekly samples of 90 leaflets (30 leaflets from each replicate representing upper, middle and lower levels of the plant) from each variety of each planting date were chosen at random in the morning and were placed in paper bags, then closed and 
transferred to the laboratory, where the number of nymphs were counted and recorded by the aid of binocular microscope.

Chemical analyses of soybean varieties were conducted at Mansoura Laboratory, Soil, Water and Environment Research. Institute, Agric. Res. Center Egypt. leaves samples were taken at the recommended planting date ( $15^{\text {th }}$ May) 60 days after planting to determine the concentrations of $\mathrm{N}, \mathrm{P}, \mathrm{K}$ and micro-elements (Zn, Fe and Mn) as described by Jones et al., (1991), Jackson (1973), Peterburgski (1968) and Chapman and Pratt (1982), respectively. Crude protein was calculated by multiplying the total nitrogen by 6.25 .

Total carbohydrates, total lipids, relative silica and total phenol were estimated using the method of Hedge and Hofreiter (1962), Anon. (1984), APHA (1992) and Malick and Singh (1980), respectively.

Statistical analysis was done using the least significant differences (LSD) at $5 \%$ level, according to Duncan's multiple range test (1955) were used and simple correlation.

\section{RESULTS AND DISCUSSION}

\section{A. Relative susceptibility of soybean varieties to infestation with $B$. tabaci at three planting dates:}

Results in Table summarized the relative susceptibility of five soybean varieties, planted at three planting dates. Mean numbers of $B$. tabaci nymphs showed highly significant differences among the tested soybean varieties during the two seasons. Giza $21 \&$ Giza 111 were the most susceptible varieties with the highest mean nymph numbers (19.39 \& 18.48 and $17.95 \& 17.36$ nymphs/30 leaflets, respectively). However, Giza 35 was the most tolerant variety to the infestation in both seasons, harboring the lowest mean numbers of nymphs (10.47 and 9.79 nymphs/30 leaflets, respectively).

However, many authors evaluated soybean varieties to infestation with whitefly. Taha et al. (2001) showed that Giza 35 and Giza 21 soybean varieties were less susceptible to whitefly. Gameih and El-Basouny (2001) who mentioned that Giza 21 was the most susceptible variety to natural infestation with whitefly nymphs ( $B$. tabaci). El-Naggar et al. (2006) reported that Giza 21 was the most susceptible variety for B. tabaci infestation followed by Giza 35 during the two seasons of study (2001 and 2002). Magouz et al. (2006) recorded the highest number of whitefly on Giza 21 and Giza 111, while the least number was existed on Giza 22. Khattab et al. (2012) found that Giza 111 and Giza 22 appeared susceptible to whitefly. 
On the other hand, Salman et al. (2002) who worked his experiments in Sohag (Upper Egypt) found that Giza 35 and Crawford were susceptible to B. tabaci ,while Giza 111 and Giza 21 were low resistant to the infestation of the pest.

This variation in susceptibility may be due to the differences in environmental factors that affect the ability of branches to resist pest attack. Thus, a variety that exhibits resistance in one locality or environment may be susceptible in another, since those factors influence fundamental physiological processes of the plant as well as the pest that might interact to make plant resistant or non resistant temporarily (Kumar,1984). Also, Metcalf and Luckmann (1975) mentioned that certain environmental conditions may alter the physiology of the plant to the extent that it becomes unsuitable as a host for a certain pest.

In general, the variations in genotypes susceptibility to the insect infestation are rarely dependent totally on a single mechanism. Van Emden (1987) reported that the variations in genotypes susceptibility to the insect infestation may be due to the presence of antixenosis and/or antibiosis phenomena. Dent (1991) mentioned that antixenosis is a resistance mechanism employed by the plant to deter colonization by an insect thereby morphological and/or biochemical characteristics of the plant. Thus, branches that exhibit antixenotic resistance would be expected to have reduced initial infestation and/or a higher emigration rate of the pest than susceptible ones. On the other hand, antibiosis is a contrast to antixenosis because it has an adverse effect on insect development, reproduction and survival. Thus, antibiotic effects may result in a decline in insect size or weight, an increased restlessness, poor accumulation of food reserves affecting the survival of hibernating or aestivating stages, or have an indirect effect by increasing the exposure of the insect to its natural enemies (Singh, 1986).

Concerning the effect of planting dates, means of B. tabaci nymphs showed highly significant differences among the three planting dates during the two seasons. The maximum mean of nymphs was recorded, on the plants of different soybean varieties planted at $1^{\text {st }}$ May planting date followed significantly by $15^{\text {th }}$ May plantation. The minimum mean of nymphs was found on $1^{\text {st }}$ June plantation.

The above mentioned results are in harmony with those of El-Srand (2014) who found that in 2010 season, the plants of the first date ( $1^{\text {st }}$ May) significantly received the highest number of the population of $B$. tabaci (nymphs and adults) while those of the mid-May and first of June exhibited the lowest number without significant among them. El-khayat et al. (2010) who found that lately planting date of cowpea harbored the lowest infestation by different stages of $B$. tabaci.

In contrary Chandel and Gupta (1995), Gad Elrab (1997) and Slman et al. (2012) found that infestation of $B$. tabaci increased with the later planting. 
However, varying the planting time of crops works as a mean of cultural control by creating asynchrony between crop phenology and the insect pest's phenology which can retard the rate of colonization (Ferro, 1987) or means that the pest fails to coincide with a critical crop growth stage (Dent,1991). Also, such methods have a major impact if the planting times were synchronized between farms within a region to reduce the variation in available crop stages. The variation in crop stages gives the insect an advantage to reproduce for longer periods. However, the differences in the insect population from one season to another may be due to the differences in the prevailing weather factors and/or the existed natural enemies.

Thus, it could be concluded that the current results might enable plant breeders to select cultivars or breeding lines that have a resistance level high enough for breeding purposes in addition to the knowledge on the relative resistance of cultivars and on the impact of cultural practices (i.e. planting dates and fertilization). The fact of great usefulness in the design of integrated management programs in an area.

Table 1. Mean number of nymphs/ 30 leaflets induced by $B$. tabaci on soybean varieties planted at three planting dates during 2011 and 2012 seasons.

\begin{tabular}{|c|c|c|c|c|c|c|c|c|}
\hline \multirow{3}{*}{$\begin{array}{l}\text { Soybean } \\
\text { varieties }\end{array}$} & \multicolumn{4}{|c|}{ Season 2011} & \multicolumn{4}{|c|}{ Season 2012} \\
\hline & \multicolumn{3}{|c|}{ Planting dates } & \multirow{2}{*}{ Mean } & \multicolumn{3}{|c|}{ planting dates } & \multirow{2}{*}{ mean } \\
\hline & $1^{\text {st }}$ May & $15^{\text {th }}$ May & $1^{\text {st }}$ June & & $1^{\text {st }}$ May & $15^{\text {th }}$ May & $1^{\text {st }}$ June & \\
\hline Crawford & $20.40 c$ & $15.36 \mathrm{c}$ & $8.06 c$ & $14.61 \mathrm{c}$ & $19.64 c$ & $14.71 \mathrm{c}$ & $7.44 c$ & $13.93 c$ \\
\hline Giza 22 & $17.38 d$ & $12.96 \mathrm{~d}$ & $6.82 \mathrm{~d}$ & $12.39 d$ & $16.96 \mathrm{~d}$ & $11.78 \mathrm{~d}$ & $5.13 d$ & $11.29 \mathrm{~d}$ \\
\hline Giza 21 & $32.38 \mathrm{a}$ & $16.80 \mathrm{~b}$ & $8.99 \mathrm{~b}$ & $19.39 a$ & $30.51 a$ & $16.02 \mathrm{~b}$ & $8.91 b$ & $18.48 \mathrm{a}$ \\
\hline Giza 111 & $26.05 b$ & $18.15 a$ & $9.66 a$ & $17.95 b$ & $25.09 b$ & $17.38 \mathrm{a}$ & $9.62 \mathrm{a}$ & $17.36 \mathrm{~b}$ \\
\hline Giza 35 & $14.53 \mathrm{e}$ & $11.04 \mathrm{e}$ & $5.83 e$ & $10.47 \mathrm{e}$ & $14.13 \mathrm{e}$ & $10.58 \mathrm{e}$ & 4.67e & $9.79 \mathrm{e}$ \\
\hline Mean & $22.15 a$ & $14.86 \mathrm{~b}$ & $7.87 \mathrm{c}$ & & $21.27 a$ & $14.09 \mathrm{~b}$ & $7.15 c$ & \\
\hline L.S.D at $5 \%$ & 0.24 & 0.22 & 0.20 & & 0.23 & 0.30 & 0.26 & \\
\hline
\end{tabular}

L.S.D at 5\%: season 2011 Variety $=1.04$, Planting date $=0.44 \quad$ season 2012 Variety $=1.4$, Planting date $=0.42$

In the same column, means followed by the same letter are not significantly different at $5 \%$ level.

\section{B. The relationships between leaves chemical components of soybean varieties and infestation with B. tabaci :}

In the second planting date, the leaf chemical analysis of the five tested varieties planted at planting date of $15^{\text {th }}$ May differed significantly in their contents of macro-elements; nitrogen, phosphorus and potassium and micro-elements; zinc, iron and manganese (Table 2).

As regarding to macro-elements, Giza 111 exhibited the highest percentage of nitrogen, but had the lowest percentage in phosphorus and potassium, while Giza 35 had the least percentage of nitrogen and the highest percentage of phosphorus and 
potassium. Concerning to the leaf contents of micro-elements, the highest content of leaves zinc and manganese were recorded on Giza 111 (57.53 and 105.93 ppm), while the lowest contents of both were recorded on Giza 35 variety (44.37 and 82.97 ppm). On the other hand, the highest iron content was detected on leaves of Giza 35, while Giza 111 had the lowest one.

A negative significant correlation was evident between the population density of $B$. tabaci (nymphs) and phosphorus, while high significant negative correlation was observed between density of $B$. tabaci and potassium and iron, but high positive significant correlation was recorded with nitrogen and manganese, and high positive significant correlation with zinc.

Statistical analysis (Table 2) revealed significant differences in leaf content of; total carbohydrates, crude protein, total lipids, silica and total phenols among the tested five soybean varieties. Leaf carbohydrate content of different soybean varieties varied significantly. The highest percentage of total carbohydrates recorded in Giza 35 (31.73\%) and the lowest percentage was recorded in Giza 111 (28.07\%). As for, the percentage of crude protein and total lipids, the highest percentages of both were recorded in Giza 111 variety (25.93\% and $15.80 \%)$, while the lowest percentages were recorded in Giza 35 (19.90\% and 12.20\%). Regarding to silica, the highest percentage was recorded in Giza $111(2.91 \%)$ and the lowest one was found in Giza $35(2.04 \%)$. The highest percentage of total phenols was recorded on Giza 35 $(0.780 \%)$, while the lowest percentage was recorded on Giza111 $(0.703 \%)$.

The population density of whitefly nymphs, were correlated with highly significant negative correlation with total carbohydrates and total phenols and highly significant positive correlation with both of crude protein and total lipids. A positive highly significant correlation was obtained between whitefly density and silica.

Results obtained in the present work are in accordance with Gamieh and ElBsiony, 2001. They reported that the soybean leaves content of nitrogen was positively correlated with $B$. tabaci nymphs, while negative correlation was detected between leaves content of potassium and B. tabaci nymphs. Magouz et al. (2006) found insignificant positive correlation between infestation of soybean with $B$. tabaci nymphs and the leaves content of nitrogen and manganese, but a negative correlation was evident between $B$. tabaci and phenols content.

Also, Hegab (2008) reported that chemical analysis results showed a positive relationship between protein with aphids and leafhoppers infestation in the faba bean varieties. Hatem (2014) reported that Aphis spp. correlated positive insignificant values with, total lipids, silica, Mn ppm., but it was negative with total phenol. Empoasca spp. population density correlated negatively insignificantly with total carbohydrates and Fe, but positively with total lipids and silica. 
Table 2. The relationships between leaves chemical components of some soybean varieties and the infestation with B. tabaci.

\begin{tabular}{|c|c|c|c|c|c|c|c|c|c|c|c|}
\hline \multirow[t]{2}{*}{ Variety } & \multicolumn{3}{|c|}{$\begin{array}{c}\text { Macro- elements } \\
(\%)\end{array}$} & \multicolumn{3}{|c|}{$\begin{array}{c}\text { Micro- elements } \\
\text { (ppm) }\end{array}$} & \multirow{2}{*}{$\begin{array}{c}\text { Total } \\
\text { carbohydrates } \\
\% \\
\end{array}$} & \multirow{2}{*}{$\begin{array}{c}\text { Crude } \\
\text { protein } \\
\quad \% \\
\end{array}$} & \multirow{2}{*}{$\begin{array}{c}\text { Total } \\
\text { lipids } \\
\% \\
\end{array}$} & \multirow{2}{*}{$\begin{array}{l}\text { Silica } \\
\%\end{array}$} & \multirow{2}{*}{$\begin{array}{c}\text { Total } \\
\text { phenols } \\
\text { \% }\end{array}$} \\
\hline & $\mathbf{N}$ & $\mathbf{P}$ & $\mathbf{K}$ & $\mathbf{Z n}$ & $\mathbf{F e}$ & Mn & & & & & \\
\hline Crawford & $3.69 c$ & $0.375 b$ & $2.10 \mathrm{~b}$ & $53.03 b$ & $116.83 \mathrm{~b}$ & $99.60 \mathrm{~b}$ & $29.80 b c$ & $23.07 c$ & $13.60 \mathrm{bc}$ & $2.53 c$ & $0.734 c$ \\
\hline Giza 22 & $3.42 \mathrm{~d}$ & $0.379 b$ & $2.13 b$ & $48.43 c$ & $121.17 a$ & $92.43 c$ & $30.73 a b$ & $21.37 d$ & $13.00 \mathrm{~cd}$ & $2.26 \mathrm{~d}$ & $0.758 \mathrm{~b}$ \\
\hline Giza 21 & $4.05 b$ & $0.357 c$ & $1.98 \mathrm{c}$ & $56.33 a$ & $114.47 \mathrm{~b}$ & $103.80 \mathrm{ab}$ & $28.80 \mathrm{~cd}$ & $25.27 \mathrm{~b}$ & $14.47 \mathrm{~b}$ & $2.74 b$ & $0.720 \mathrm{~d}$ \\
\hline Giza 111 & $4.15 a$ & $0.348 d$ & $1.93 c$ & $57.53 a$ & $108.77 \mathrm{c}$ & $105.93 a$ & $28.07 d$ & $25.93 a$ & $15.80 \mathrm{a}$ & $2.91 a$ & $0.703 \mathrm{e}$ \\
\hline Giza 35 & $3.18 \mathrm{e}$ & $0.387 a$ & $2.21 a$ & $44.37 d$ & $122.97 a$ & $82.97 d$ & $31.73 a$ & $19.90 \mathrm{e}$ & $12.20 \mathrm{~d}$ & $2.04 \mathrm{e}$ & $0.780 \mathrm{a}$ \\
\hline $\mathrm{LSD} \mathrm{t}_{5 \%}$ & 0.09 & 0.007 & 0.06 & 1.84 & 3.47 & 5.67 & 1.20 & 0.56 & 0.94 & 0.10 & 0.011 \\
\hline \multicolumn{12}{|c|}{ Correlation coefficient values } \\
\hline Whitefly & $+0.9893^{* *}$ & $-0.9514^{*}$ & $-0.9654^{* *}$ & $+0.9936^{* * *}$ & $-0.9724^{* *}$ & $+0.9805^{* *}$ & $-0.9939^{* * *}$ & $+0.9901^{* *}$ & $+0.9651^{* *}$ & $+0.9981^{* * *}$ & $-0.9973^{* * *}$ \\
\hline
\end{tabular}

Means followed by the same letter are not significantly different at $5 \%$ level. * (Significant at $P \leq 0.05$ ) and ** (Significant at $P \leq 0.01$ ) 


\section{REFERENCES}

1. Anonymous. 1984. Official methods of analysis" $13^{\text {th }}$ Ed. Published by the Association of Official Analytical chemists (A.O.A.C.), Washington. Dc. U.S.A.

2. APHA. 1992. Standard methods for the estimation of water and plant" $18^{\text {th }}$ edd. American Public Health Association. Washington D.C.

3. Chandel, Y.S. and R.K. Gupta. 1995. Effect of sowing date on incidence of insect pests of soybean (G/ycine max). Indian J. Agric., 65 (8): 624-625.

4. Chapman, H.D. and F. Pratt. 1982. Methods of soil analysis. Part 2 A.S.S. Madison Wisconsin.

5. Dent, D. (1991): Insect pest management. C.A.B. International., pp. 213.

6. Duncan, D. B. (1955): Multiple range and multiple $F$ tests. Biometrics 11:1-42.

7. El-khayat, E.F., F.A. El-Lakwah, G.H.H. Rady, Mona M. A. Ghallab and B.S. Wahba. 2010. Impact of planting dates on infestation of cowpea plants with some pests. Egyptian J. Agric. Res., 88 (4): 1107-1120.

8. El-Komy, S.O.O. and K.A.M. Aly. 2004. Evaluation of some soybean genotypes for resistance to cotton leaf worm, Spodoptera littoralis (Boisd.) infestation. Minufiya J. Agric. Res. Vol. 29(5): 1215-1226.

9. El- Naggar, M.E., N.F. Abdel- Baky, A.M. Abou El-Naga and G.A.M. Hekal. 2006. Sensitivity of three soybean varieties for Bemisia argentifolii (Homoptera: Aleyrodidae) infestation and role of the internal leaf biochemicals. Egypt. J. Agric. Res., 84 (2):405-419.

10. El-Samahy, M.F.M and I.A.I. Saad. 2010. Population density of certain piercing sucking pests on three varieties in relation to some leaf characteristic. J. Plant Prot. and Path., Mansoura Univ., 1(10): 767-773.

11. El-Srand, A.E. 2014. Integrated management of certain piercing-sucking insects on soybean and faba bean plants at Kafrelsheikh Governorate. Ph.D. Thesis, Fac. of Agric., Tanta Univ., pp. 192.

12. Ferro, D.N. 1987. Insect pest outbreaks in agroecosystem. In Barbosa, P. and Schutlz, J.C. (eds), insect outbreaks. Academia press, San Diego and London, pp. 195-215. (In. Dent, 1991). Insect Pest Management C.A.B. internacional, pp. 384.

13. Gad El-Rab, M.L.E. 1997. Entomological studies on soybean, maize and sorghum under different intercropping systems in upper Egypt. Ph.D. Thesis Fac. Agric. Minia Univ., Egypt, 178-181. 
14. Gamieh, G.N. and A.A. El-Basiony. 2001. Population densities of piercing sucking pests in soybean fields influenced by varieties, predators and leaf physical and chemical properties. J. Agric. Sci. Mansoura Univ., 26(2): 1089-1099.

15. Hatem, A.E.A. 2014. Studies on insect pests infesting leguminous plants and their natural enemies at Kafrelsheikh. B. Sci. Thesis. Economic Entomology, Kafrelsheikh Univ.

16. Hedge, I.E. and Hofreiter, B.T. 1962. Carbohydrate Chemistry i7 (Eds Whistler R.L. and Be Miller, J.N.) Academic Press New York.

17. Hegab, O.M. (2008). Susceptibility of six faba bean varieties to certain Homopterous insects infestation and transmission efficiency of faba bean Necrotic Yellow Virus. J. Agric. Sci. Mansoura Univ., 33(3): 2291-2303.

18. Jackson, M.L. 1973. Soil chemical analysis. Prentic-Hall of India-Private, New Delhi, PP. 144-197.

19. John, W.N. JR; S. Marla and M. Katherine. 1986. Toxicity of clorfentezine against the two spotted and carmine spider mite (Acari : Tetranychidae).J. Econ. Entomol., 79(2): 479-483.

20. Jones, I.R., I. Benton, B. Wolf and H.A. Mills. 1991. Plant analysis. Hand book, Methods of plant analysis and inter-predation. Micro-Macro. Publishing, inc., USA. pp. 30-34.

21. Khattab. M.A.A., A.M. Nassef and E.M.E. Khalafalla. 2012. Relative susceptibility of some soybean varieties to the main piercing-sucking insects infestation in Kafrelsheikh Governorate. J. Plant Prot. and Path., Mansoura Univ., 3 (7): 751756.

22. Kumar, R. 1984. Insect pest control with special reference to African Agriculture. Edward Arnold, London, pp. 298.

23. Magouz, R.I.E., S.E. Saadoon and S.A.A. Kassem. 2006. Population density of Tetranychus cucurbitacearum (Sayed) and Bemisia tabaci (Genn.) on certain soybean varieties in relation to some weather factors and leaf chemical contents. J. Agric. Res. Tanta Univ., 32 (1): 95 - 102.

24. Malick, C.P. and Singh, M.B. 1980. Plant Enzymology and Histo Enzymology Kalyari" Publishers New Delhi, P.286.

25. Marlin, E.R. and O.N. Matt. 2007. Soybean insecticides for 2007. This article originally appeared on pages 79-80 of the IC-498(3) - March 26, 2007 issue.

26. McAuslane, H.J. 1996. Influence of leaf pubescence on ovipositional preference of Bemisia argentifolii (Homoptera: Aleyrodidae) on soybean. Environ. Entomol., 25(4): 834-841. 
27. Metcalf, R.L. and W.H. Luckmann. 1975. Introduction to insect to African management. John Wiley and Sons Inc., New York, pp. 587.

28. Peterburgski, A.V. (1968): Hand Book of Agronomic Chemistry. Kolas publishing House, Moscow, (in Russian), pp. 29-86.

29. Salman, F.A.A., A.M. Mohamed, H.A. Mohamed and M.L.S. Gad El-Rab. 2002. Evaluation of some soybean varieties to natural infestation with whitefly Bemisia tabaci (Genn.) and spider mite Tetranychus urticae (Koch.) in upper Egypt. Egyptian J. Agric. Res., 80: 619-629.

30. Singh, D.P. 1986. Breeding for resistance to diseases and Insect pests.Spring Verlag, New York and Heidelberg.

31. Slman, F.A.A., W.A. Mahmoud, M.A. Ahmed and R.A.M. Amer. 2012. Effect of some agriculture practices on the infestation of soybean (Glycine max L.) with Tetranychus urticae (koch.) and Bemisia tabaci (Gen.) in Sohag Governorate. Egyptian J. Agric. Res., 90 (3).

32. Taha, H.A., A. A. Shoeib, A. A. Younes and M.A. Ahmed. 2001. Susceptibility of ten soybean varieties to with respect to certain climatic factors ineffectiveness. J. Agric. Sci., Mansoura Univ., 26:5059-5066

33. Van Emden, H.F. 1987. Cultural methods: the plant. In: Burn, A.J.; T.H. Coaker and P.C. Jepson (Ed.) Integrated pest management, 27-67, Academic Press, London, New York. 


\section{حساسية بعض أصناف فول الصويا وتأثير مواعيد الزراعة على الإصابة بالذبابة البيضاء فى منطقة كفر الثيخ}

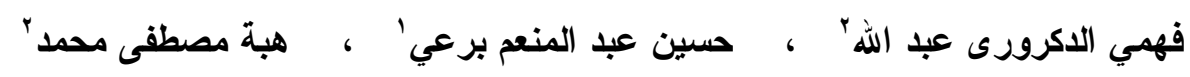

ا ـ قسم الحشرات الافتصادية- كلية الزراعة- جامعة كفر الشيخ

r. قسم بحوث أفات محاصيل الحقل - محطة بحوث سخا - معهز بحوث وقاية النباتات- مركز

$$
\text { البحوث الزراعية }
$$

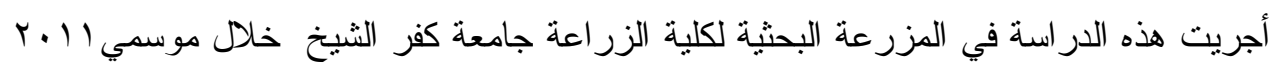

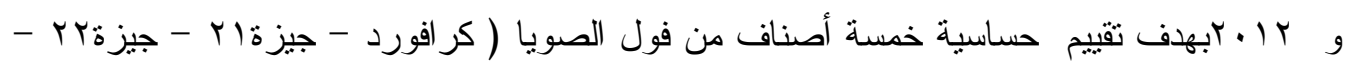

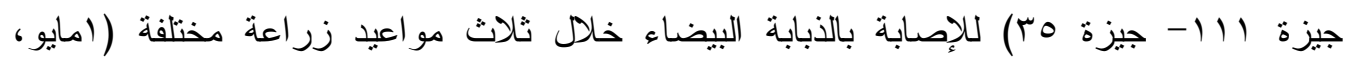

$$
\text { ه (مايو، (يونيو). }
$$

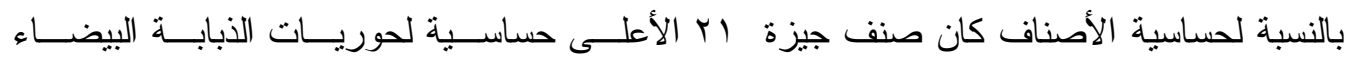
خلال موسمي الدر اسة، بينما كان صنف جيزة هب الأقل إصابة بهذه الحشرة.

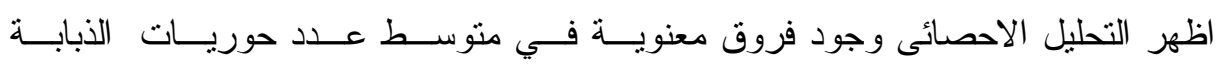

$$
\text { البيضاء وبين أصناف فول الصويا خلال موسمي الدر اسة . }
$$

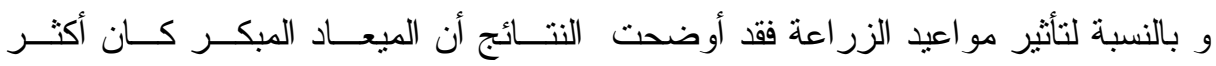

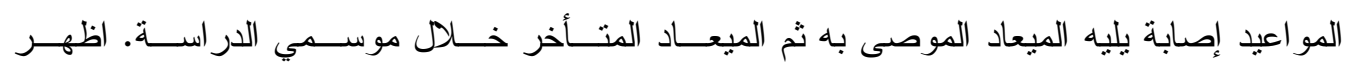
التحليل الاحصائى وجود فروق معنوية بين مو اعبد الزر اعة الثناثة.

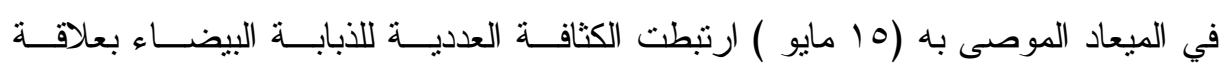

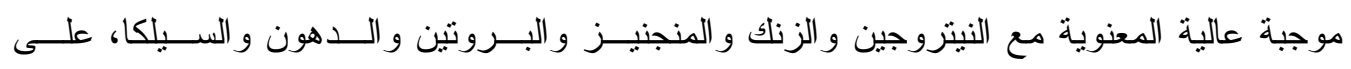

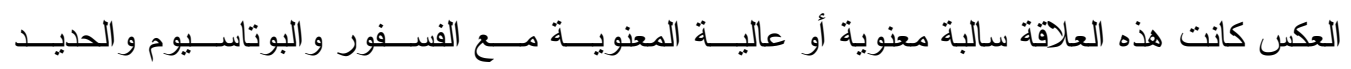
و الكربو هيدر ات و الفينو لات.

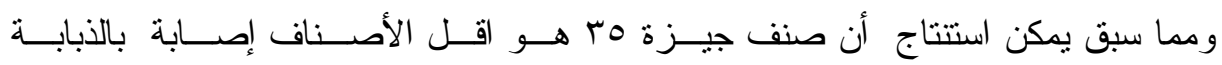

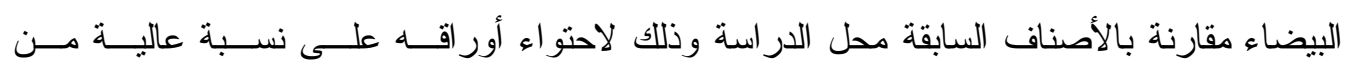
الكربو هيدر ات و الفينو لات و الحديد و الفوسفور و البوتاسيو . 